(C) 2014

\author{
Литвин О. Ю., кандидат економічних наук
}

Полтавська державна аграрна академія

\title{
ЕКОНОМІЧНІ ІДЕЇ ХРИСТИЯНСТВА ЯК ОСНОВА МОЖЛИВОЇ ПОСТКРИЗОВОЇ ЕКОНОМІЧНОЇ СТРАТЕГІЇ УКРАЇНИ
}

\author{
Рецензент - доктор економічних наук, професор А. О. Пантелеймоненко
}

У статті розглянуто основні економічні ідеї християнства. Аналізуються публікації українських $i$ російських дослідників, церковних істориків і публіцистів, присвячені дослідженню иієї проблеми. Доводиться актуальність $і$ значимість економічних ідей християнства, фокусується увага на їх впливі на сучасну економіку. Акцентовано увагу читачів на тому, шзо економічні ідеї християнства потрібно розглядати не лите в контексті розвитку самого християнства та економічної думки, але й пов'язувати їх із можливою національною посткризовою економічною стратегією Украӥни.

Ключові слова: християнство, Біблія, лихвар, ідея, економіка.

Постановка проблеми. Важливою проблемою сьогодення $\epsilon$ пошук шляхів стимулювання розвитку економіки та їі модернізації з метою підвищення добробуту населення. Українське суспільство потерпає від бідності. Якщо на початку 2012 р. мінімальна зарплата в Україні становила 117 євро, то у провідних європейських країнах вона була більшою у 10-12 разів. Гарантована мінімальна заробітна плата в Німеччині на той час становила 1442 євро, в Ірландії 1432, в Бельгії -1387, у Нідерландах - 1382, у Франції - 1321 євро. Проте витрати українців на першочергові потреби більші, ніж у європейців. Частка комунальних витрат у структурі доходів українців становить близько $40 \%$, у Європі $20 \%$, витрати на харчування - 15-20\% бюджету родини, а в європейських країнах $-8-10 \%$.

Бідність переважної частини населення породжує інші соціальні проблеми. Так, наприклад, в Україні нині нараховується близько 100 тисяч бездомних дітей, а $30 \%$ українських чоловіків не доживає до пенсії. Цю жахливу статистику можна продовжувати. I в той же час українські багатії посідають провідні місця у рейтингах найбагатших людей Європи і світу. Де шукати вихід? Як змінити ситуацію?

Українське суспільство - це, переважно, християнське суспільство. I тому одним із можливих шляхів виходу з кризи є повернення до християнських канонів, нове переосмислення економічних ідей християнства i їх використання.
Аналіз останніх досліджень і публікацій, у яких започатковано розв'язання проблеми. У науковій літературі (не богословській) дослідженню питання економічних ідей християнства приділено недостатньо уваги, а в наявних публікаціях питання висвітлюється однобічно. Зокрема, такі відомі науковці як В. М. Ковальчук, М. В. Лазарович, М. І. Сарай, П. І.Юхименко, П. М. Леоненко, Б. Д. Лановик, 3. М. Матисякевич, Р. М. Матейко розглядають економічні ідеї християнства досить стисло, виключно в контексті розвитку самого християнства та економічної думки, не пов'язуючи їх із можливою національною посткризовою економічною стратегією України.

Мета дослідження: інформування населення про значний потенціал економічних ідей християнства для пошуку механізмів вирішення сучасних економічних проблем в Україні. Основним джерелом економічних ідей християнства $є$ Біблія [1]. Тому дослідження тексту Священної книги, виділення й осмислення основних економічних ідей $\epsilon$ найважливішим завданням дослідження. Саме це й визначає актуальність даної публікації.

Матеріали та методи дослідження. Для досягнення поставленої мети використані принципи системного аналізу та фундаментальні положення інституціональної економічної теорії. Для побудови логіки й структури роботи застосовувався метод структурно-логічного аналізу. Використовувалися також методи історико-ретроспективного та причинно-наслідкового аналізу. Методи комплексного й системного підходу використані на етапі формулювання висновків.

Результати досліджень. Автори й упорядники Біблії виступали категорично проти відбирання власності у ближнього, злочинів економічного характеру. Восьма заповідь Закону Божого - «не кради». Забороняється крадіжка, тобто привласнення в будь-який спосіб того, що належить іншим. До того ж види крадіжки можуть бути різними: крадіжка - як викрадення чужих речей; грабунок - насильне відбирання чужих речей; святотатство - присвоєння власності 


\section{EKOHOMIKA}

церкви; хабарництво - коли посадові особи незаконно беруть дари від людей, чиї прохання зобов'язані виконувати безплатно за своєю посадою; дармоїдство, коли отримують платню за роботу, але нічого, по суті, не виконують; здирництво - коли беруть чималі гроші, користуючись людською бідою, іноді забираючи останнє майно; обман - привласнення чужого майна хитрощами [2, с. 532-533].

Крім того Біблія засуджує накопичення надмірного багатства. (Як це актуально і значимо для нинішнього суспільства, орієнтованого на збагачення будь-якою ціною! Дехто із сучасних багатіїв навіть не приховує, що свій перший капітал вони заробили кримінальним шляхом). «Глядіть, остерігайтесь користолюбства (тобто необхідно остерігатися любові до багатства, пристрасті до збагачення), бо життя людини не залежить від багатства іï маєтку», - вчив Ісус Христос. Для кращого розуміння слів він розповідав притчі. Одна 3 них - про нерозумного багача.

В одного багатого чоловіка добре вродила нива. I він став міркувати про себе: «Що мені робити? Немає куди мені зібрати плодів моїх». I, вирішивши, сказав: «Ось що зроблю: зруйную житниці мої та збудую більші, і зберу туди хліб мій і все добро моє. I скажу душі моїй: душе моя, багато маєш добра, що лежить у тебе на багато років, споживай, їж, пий, веселись».

Однак Бог сказав йому: «Нерозумний! Цієї ночі душу твою візьмуть у тебе (тобто, ти помреш); кому ж дістанеться те, що ти наготував?» Закінчивши цю притчу, Господь сказав: «Так буває 3 тим, хто збирає скарби для себе, а не в Бога багатіє» [1, Лк. 12, 15-31].

Це, вчить Біблія, спіткає кожну людину, яка збирає багатство тільки для себе, для своїх вигод i власного задоволення, а не для добрих угодних Богу справ - не допомагає ближнім, не полегшує їхніх страждань. Прийде смерть до людини, i земне багатство не принесе душі їі ніякої користі.

В Євангелії від Марка стверджується, що «легше верблюду пройти крізь вушко голки, ніж багатому ввійти до царства Божого» [3, с. 294].

Економічні погляди християнства грунтуються на рівності всіх людей перед Богом, справедливості, соціальній оцінці праці. «Якою мірою міряєте, - говорить Христос у Свангелії від Матвія, - такою буде відміряно й вам». Аби відповідати християнському ідеалу, радилося або продати все своє майно, або роздати його нужденним [3, с. 294].

Дослідники зазначають, що Біблія засуджувала лихварство і боргове рабство [3-5]. В одній із притч, які розповідав Ісус Христос, ідеться про чоловіка, який заборгував царю десять тисяч талантів. Та він не мав чим сплатити борг. Коли його привели до царя, то цар наказав продати його, i дружину його, і дітей, продати все майно й віддати борг. Коли боржник упав на коліна перед царем і став благати його відтермінувати строк повернення боргу, милостивий цар зглянувся над ним, простив йому увесь борг і відпустив. Той самий чоловік, вийшовши від царя, побачив одного зі своїх товаришів, який позичив у нього сто динаріїв (суму в мільйон разів меншу, ніж був борг цареві самого цього позикодавця). Він схопив його, почав душити, вимагаючи повернути позичені гроші. Товариш його упав на коліна перед цією людиною, благаючи: «Потерпи, все віддам тобі». Проте чоловік цей не захотів чекати, а пішов і посадив його у в'язницю, аж поки не поверне боргу. Коли цар довідався від товаришів потерпілого про жорстокість цього чоловіка, то покликав його до себе і сказав: «Рабе лукавий! Весь той борг я простив тобі, бо ти ублагав мене. Чи не належало й тобі помилувати товариша твого, як і я помилував тебе?» I, розгнівавшись, цар віддав його людям, які карали злочинців-мучителів, доки не поверне несплачений борг» [1, Мф 18, 21-35; Лк. 17, 3-4].

Ще одним підтвердженням негативного ставлення до ідеї стягнення процента за позику є слова Христа: «Давайте в позику, не очікуючи нічого», - про що згадується в Євангелії від Луки [3, с. 294].

Аналіз Біблійських текстів свідчить про високий рівень розвитку торгівлі, широке розповсюдження грошей серед стародавніх жителів Палестини, наявність, навіть, таких спеціальностей, як «міняльники грошей». Проте відношення до торгівлі мінял і лихварів переважно негативне: «Ісус Христос... прогнав 3 храму всіх торговців, столи міняйл поперекидав, а гроші їхні розсипав. I сказав продавцям голубів: «Візьміть це звідси, i не робіть дому Отця Мого домом торгівлі» [1, Ін. 2, 13-25]. В іншому місці священної книги, описуючи вхід Господа в Ієрусалимський храм, знову замальовується подібна ситуація: увійшовши в храм Христос знову, як це вже було колись, вигнав із нього всіх продавців і покупців, кажучи їм: «Написано: дім Мій є дім молитви, а ви зробили його вертепом розбійників» [1, Пс. 8:3] (тут продавці навіть порівнюються 3 розбійниками).

Християнство підтримувало й схвалювало сплату державних податків. Відому фразу «Віддавайте кесареві кесареве, а Боже - Богові» відповідь Ісуса Христа на питання: «Чи годиться 


\section{EKOHOMIKA}

платити кесареві?» слід розуміти так: потрібно сплачувати податок кесареві, бути покірним йому в усьому, що не суперечить Божим заповідям. Сплата податку - законний обов'язок і необхідність.

Християнство закликало бути милостивими. Діла милості бувають духовними і тілесними. Діла милості матеріальні (тілесні): голодного нагодувати, спраглого напоїти, голого одягти, хворого відвідати й посприяти його одужанню, мандрівника прийняти у дім і надати йому спочинок, ховати померлих бідняків. Ці положення, як зазначають дослідники, по суті, повинні були підтримувати соціально-економічну стабільність, мир і спокій тодішнього суспільства $[6,7]$.

Християнство засуджувало лінощі та недбальство, закликало віруючих посилено працювати шість днів на тиждень, а один день - відпочивати, присвятити Богу. Четверта заповідь Закону Божого - «Пам'ятай день суботній, щоб святити його: шість днів працюй i виконуй у них всю роботу свою, а день сьомий - субота для Господа твого».

Християнство визнавало працю основою люд-

\section{БІБЛІОГРАФІЯ}

1. Библия. Книги Священного Писания Ветхого и Нового Завета - М. : Издание Московской Патриархии, 1988. - 1371 с.

2. Большая иллюстрированная энциклопедия истории / [пер. 3 англ. М. Берденнікова] - М. : Махаон, 2005. - 491 c.

3. Ковальчук В. М. Економічна думка минулого і сьогодення [навч. пос.] / В. М. Ковальчук, М. I. Сарай. - Тернопіль : ТАНГ «Астон», 2000. $-325 \mathrm{c}$.

4. Ковальчук В. М. Історія економіки та економічної думки: [навч. пос.] / В. М. Ковальчук, ського життя й проголошувало принцип всезагальності праці та рівної оплати за рівну працю. Відомі гасла: «Якщо хтось не хоче працювати, хай i не їсь», «Кожен отримує винагороду за працею своєю» проголосив апостол Павло [3, с. 294].

Вважалося, що всі люди отримують від Господа різні дари: життя, силу, здоров'я, життєві блага. Бог же знає, скільки потрібно дати кожному за його здібності, тому й отримують - хто більше, хто менше. Хто як скористався цими дарами, в тому кожна людина повинна звітуватися перед Богом [1, Мф. 25, 14-30; Лк. 19, 1-28].

Висновок. Таким чином, економічні ідеї християнства, викладені у Бібліі, ніскільки не втратили своєї важливості й значимості в наш час, а, навпаки, в умовах розбрату, зневіри й невпевненості вони стали тим орієнтиром, який веде нас до пізнання істини. Зерна розумного й вічного, закладені в Біблії, повинні поступово змінювати ментальність українського суспільства. Вони можуть бути покладені в основу можливої національної посткризової економічної стратегії, можуть бути наріжним каменем в осмисленні й формуванні української національної ідеї.

М. В. Лазарович. - К. : Знання, 2008. - 647 с.

5. Лановик Б. Д. Історія господарства: Україна i світ / Б. Д. Лановик, 3. М. Матисякевич, Р. М. Матейко. - К. : Вища школа, 1995. - 480 с.

6. Серафім Слобідський. Закон Божий. [Підручник для сім'ї та школи]. - К. : Видавничий відділ Української Православної Церкви Київського Патріархату, 2003. - 654 с.

7. Юхименко П. І. Історія економічних учень: [навч. пос.] / П. І. Юхименко, П. М. Леоненко. К. : Знання Прес, 2001. - 514 с. 